\title{
PERCEPTIONS OF ENERGY CROP PRODUCTION BY LAY PEOPLE AND FARMERS USING THE ECOSYSTEM SERVICES APPROACH
}

\author{
Gerd LUPP, Olaf BASTIAN, Reimund STEINHÄUßER, Ralf-Uwe SYRBE
}

\begin{abstract}
Perceptions of energy crop production are assessed in this paper. The Görlitz district (Germany) serves as a case study area for this purpose. Semi-structured interviews with farmers and standardized surveys among lay persons were conducted. Many farmers perceive themselves being responsible for providing many ecosystem services. Farmers prefer a regional scale of energy crop cultivation based on conventional crops. Improved legal frameworks and incentives would safeguard equal competition and ecosystem services. Laypersons think that drinking water, food production, biodiversity and pollination are the most important ecosystem services of agricultural landscapes. Providing biomass for renewable energy production is not considered to be an important ecosystem service. Laypersons believe that biomass production should be restricted to fields that are not needed for food production, and the use of residues or landscape management materials. According to laypersons, more money should be spent to halt the decline of ecosystem services.
\end{abstract}

\section{Shrnutí}

\section{Výzkum vnímání produkce energetických plodin laickou veřejností a zemèdělci s využitím přistupu ekosystémových služeb}

$V$ tomto článku je hodnoceno vnímání produkce energetických plodin. Jako př́padová studie slouži okres Görlitzv Německu. Byly uskutečněny semi-strukturované rozhovory se zemědělci a standardizovaná dotazníková šetření s laickou veřejností. Většina farmářu vnímá sama sebe jako poskytovatele mnoha ekosystémových služeb. Farmáři preferuji pěstování konvenčních energetických plodin s podporou na regionální úrouni. Lepši legislativní nástroje a dotace by podle nich zajistily rovnou soutěž a ekosystémové služby. Laická veřejnost se domnivá, že pitná voda, produkce potravin, biodiverzita a opylení predstavuji nejdůležitějši ekosystémové služby, které poskytuje zemědělská krajina. Zajištění biomasy pro produkci obnovitelné energie není považováno za důležitou ekosystémovou službu. Laická veřejnost má za to, že produkce biomasy by měla být omezena na plochy, které nejsou potrebné pro produkci potravin, využití zbytkových produkti̊ či management krajiny. Více peněz by naopak mělo být věnováno proti úpadku ekosystémových služeb.

Key words: Energy crops, biomass, bioenergy, ecosystem services, perception, farmers, laypersons, Görlitz district (Germany)

\section{Introduction}

The European Commission and the German government have set ambitious goals for future renewable energy production (EC, 2009; Bundesregierung Deutschland, 2010). The aim of the energy transition is to reduce carbon emissions as part of limiting climate change, and of achieving strategic goals to reduce dependency on such imported non-renewable energies as oil and natural gas. A target set for renewable-energy use by 2020 for the EU is $20 \%$ of total energy consumption (Commission of the European Union 2007). Germany's targets are an $18 \%$ share of total energy consumption to be supplied from renewable sources by $2020,30 \%$ by $2030,45 \%$ by 2040 and $60 \%$ by 2050 (BMU, 2010), although it is not defined if such energy would be produced abroad or from within the country. Biomass from wood and energy crops is considered an important factor in meeting these policy goals. For that purpose, the cultivation of biomass for energy production would have to be doubled by 2020 at the European level, as well as in Germany (Commission of the European Union, 2005; Kavalov and Petkeves, 2005; BMELV and BMU, 2009). To reach that policy objective, between $21 \%$
(Agentur für Erneuerbare Energien, 2012) and 30\% (SRU, 2007) of all German agricultural areas would have to be used exclusively for energy crops, which would change German agricultural landscapes significantly. The increase in the cultivation of non-food crops would force food production to be intensified, resulting in more pressure on ecosystem services.

By 2012, energy crops were already being cultivated on $2,124,500$ ha, or on more than $17.6 \%$ of Germany's arable land. The most important crops in 2012 included rapeseed for biodiesel and blended fossil fuels, cultivated on 913,000 ha (the produced fuels, however, provide only a negligible share of demand in the German transport sector), and various crops for biogas production, on 962,000 ha (FNR, 2012), including 800,000 ha used for corn (Zea mays) (Deutscher Bauernverband, 2012). Energy derived from biomass accounted for $6.1 \%$ of electric power production (mainly biogas), for $10.1 \%$ in the heating sector (mainly wood biomass), and for 5.5\% in transportation (mainly rapeseed oil, ethanol derived from grain and sugar beets) (Agentur für Erneuerbare Energien, 2013). The extent of the cultivation 
of energy crops and silage corn varies significantly by region. According to Maiskomitee (2012), corn is grown on about 20\% of the farmland in most districts in eastern Germany, while in some districts of Lower Saxony, such as Ammerland and Wesermarsch, intensive livestock farming had already given rise to intense cultivation of corn for fodder, even prior to the boom of bio-energy. The biogas plants then led to a further increase in corn cultivation, such that corn covered more than $70 \%$ of the farmland in some of these districts in 2011 (Deutsches Maiskomitee, 2012).

Scientists, policy makers and various stakeholder groups have discussed the negative impacts of these developments on biodiversity, ecosystems and their services, vigorously. Various impacts on ecosystem services are already visible and would further increase if the regulation and steering of bio-energy production is not improved significantly in the future (Bastian et al., 2013). Intensive corn cultivation, in particular, can threaten such environmental assets as biodiversity, soil fertility, pollution control and water conservation (Lee et al., 2008; Greiff et al., 2010), and lead to uniform and monotonous landscape structures, resulting in dramatic changes in the character of the landscape. Corn needs high nitrogen inputs and shows significant nitrogen spill-over and high erosion rates. The cultivation of such water- demanding crops as corn is considered a problem, especially in view of the fact that climate change could cause a decline in water availability (Hall et al., 1996; Heidmann et al., 2000). Moreover, it has been observed that high natural value grasslands are being converted into fields for energy crops, or to replace fields used for their production (indirect land use change). In Germany, approximately $0.9 \%$ or 188,000 ha of grasslands were lost by conversion to farmland between 2005 and 2009 (Schramek et al., 2012). Grassland conversion to arable land for energy crop cultivation can lead to carbon emissions from the soils that outweigh the greenhouse gas reductions due to bioenergy use (McLaughlin and Walsh, 1998; Rowe et al., 2009).

On the other hand, such perennial crops as cup-plants (Silphium perfoliatum), wood biomass (e.g. short-rotation coppice), or landscape management materials, are alternatives with higher net greenhouse gas reduction and less impact on many ecosystem services (ES) than conventional crops. According to Cherubini and Strømman (2011), biomass production based on perennial crops or material from landscape management (grasses, herbaceous plants, wood) allows for the minimization of such inputs as fertilizers, tillage or herbicide use. Short-rotation coppices also increase structures in intensively used agricultural areas, and provide space for nesting birds (Liesebach and Mulsow, 2003), and even some Red List species (Burger, 2006). They may also increase scenic qualities and contribute to a green infrastructure (Londo et al., 2004) in intensively-used agricultural landscapes. The existing incentives, particularly the German Renewable Energy Act (EEG) and the Common Agricultural Policy of the EU (CAP) and various legal frameworks and planning tools, however, are not powerful enough to support more environmentally-friendly crops like perennials, residues or wood biomass (Lupp et al., 2014).

In this paper, we examine the extent to which the cultivation of energy crops (especially corn) and their impacts on the environment, are issues among farmers and lay people. We analyse not only how they perceive the increasing share of energy crops, but also how the alternative, less harmful sources of biomass for energy-production purposes, such as landscape-management materials, short-rotation coppices or perennial crops, might be attractive options for farmers. We assess what conditions might be favourable from a farmer's point of view to support the cultivation of alternative dedicated energy crops, and what kind of policy support by incentives or regulations, would be necessary to make them an attractive option for cultivation. By questioning lay people, we tried to assess the attitude of the public to bio-energy production, and their perceptions of the state of agriculture and energy-crop production in their region. In particular, we asked whether an enhanced provision of different ecosystem services (ES) in agricultural landscapes would be appreciated, and which ES would be considered most important.

\section{Material and methods}

Due to the diversity of natural, geographical and spatial features, a research design using a case study at the landscape level is a very promising approach (Rode and Kanning, 2006). The case study approach allows precise investigations of actual effects, rather than only theoretically possible effects. For the case study, we developed an approach of actively involving such stakeholders as energy crop farmers, planners and decision makers in the research process, in order to incorporate their knowledge, preferences, views, values and attitudes. One of the main goals of the research project is to involve and motivate stakeholders to shape, suggest and decide about future biomass production for energy purposes, so that they may benefit directly from the research results. Our assumption is that a combination of different local and scientific knowledge sources will best be able to cope with uncertainties and presumptions. The results of this procedure will provide the basis for more robust decision making.

\subsection{Study area: The Görlitz district}

We have chosen the easternmost German district of Görlitz, in the federal state of Saxony, as our case study region (Fig. 1). With its rather continental climate, the

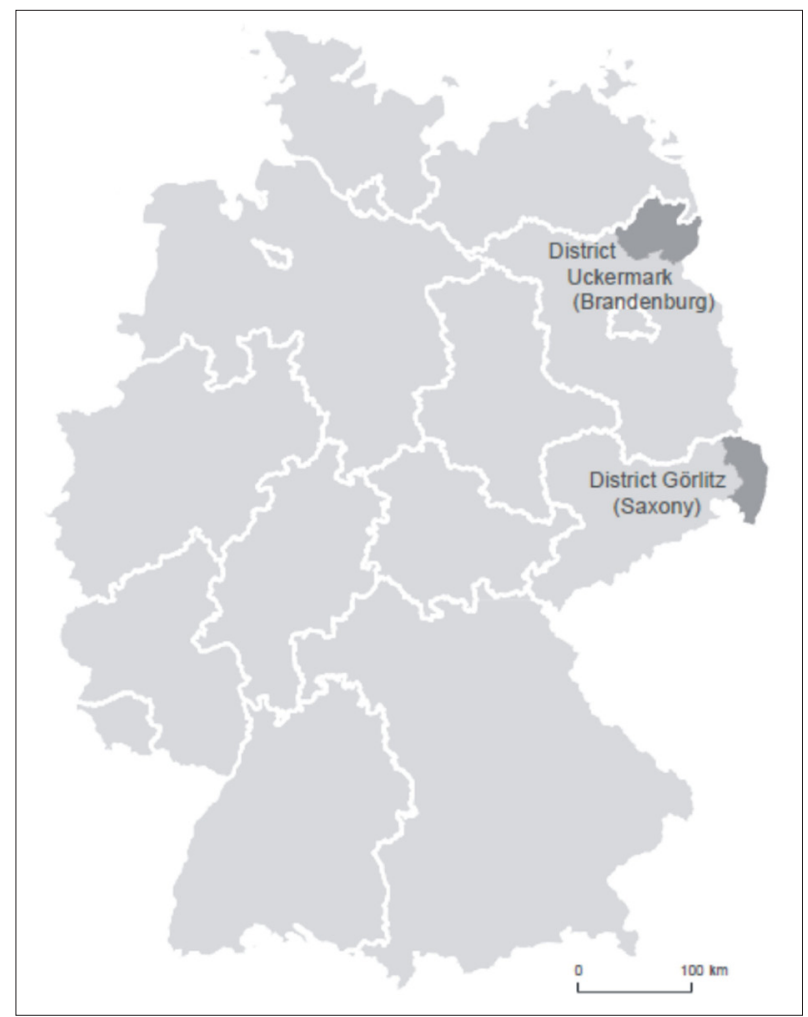

Fig. 1: The case study district of Görlitz and the district of Uckermark 
district is characterized by warm, mild summers and cold winters. Its 210,620 ha area provides a cross section of many relevant physical regions typical of Central Europe; its population was 264,673 in 2012 (Destatis, 2013). The north of the district is part of the North German Plain, characterised by poor sandy soils, and large Scots pine (Pinus sylvestris) forests, but it has also been transformed by largescale opencast lignite mining. The central and southern parts are characterised by very fertile hilly landscapes with loess soils. The city of Görlitz is the main urban area with some 54,000 inhabitants (Zensuskarte, 2013). The southernmost part of the district is dominated by the low Zittau mountain range. The district has been affected by demographic change and is seeking new opportunities for the future, including the possibility of becoming an important producer of renewable energy in Germany.

\subsection{Current situation of energy crops in the Görlitz district}

It is somewhat difficult to analyse the actual share of energy crops in the Görlitz district. Since farmers usually sell their crops to middlemen, who decide on a day-to-day basis whether they are to be sold for energy production, feed, or to the food industry, it was not possible to ascertain the spatial extent of corn used for energy production by interviewing farmers, nor could we obtain such information from the middlemen. To assess the demand for corn silage for bio-energy use, we therefore marked all sites of operating biogas plants in the Görlitz district by GIS, using a database in which all biogas plants are registered. Under the law, the operators have to describe accurately what amount and type of raw materials they use in their power plants. To ascertain the amounts of renewable raw materials used in the power plants, we thus calculated the need for farmland, using yields per hectare and regional soil fertility, and factored in a minimum crop rotation, assuming 50\% corn (cultivation of corn in every second year), which was considered a kind of minimum standard among farmers. Assuming that fields providing feedstock for the power plants are located as close to them as possible to avoid long and costly transport, we then assessed the amount of farmland that each biogas plant would need in its own vicinity, using a GIS algorithm (Fig. 2).

It seems likely that in some areas, especially in the south of the district, most of the fields are needed for biogas plants and therefore will be cultivated with corn regularly.

\subsection{The concept of Ecosystem Services}

To assess the consequences of increased energy crop cultivation, we use the concept of Ecosystem Services (ES) as a theoretical framework. This concept stresses the essential relevance of ecosystem structures and processes to human well-being. It encompasses both the supply of services, which is based on structures, processes and potentials of ecosystems, and the demand for these services by individuals, groups of stakeholders, or society as a whole. The attractiveness of the ecosystem services concept is its integrative and interdisciplinary nature, and the fact that it is seen as an innovative way towards more sustainable land use practices (BMBF, 2008; Weith et al., 2010). Therefore, the concept can play a role as an eye-opening metaphor and a tool for society and decision makers to think about the importance of nature and its degradation (Norgaard, 2010). The assessment of the demand for non-market goods (e.g. the demand for attractive sceneries) can be carried out by such methods as stated preference techniques, choice experiments, willingness to pay (WTP) to maintain

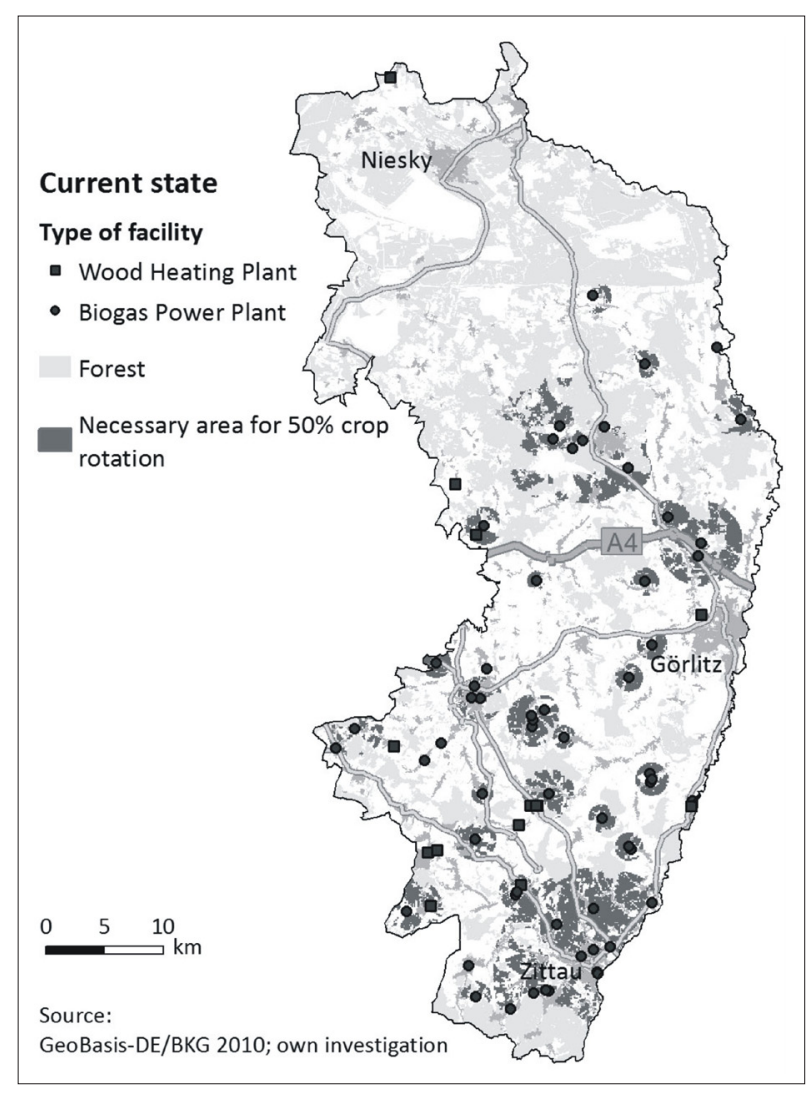

Fig. 2: Spatial extent of corn plantations for the existing biogas plants

biodiversity, target species, ecosystem services, landscape elements and aesthetic values (Schweppe-Kraft, 2009). Especially the ranking and weighting of ES has to date received only limited attention (Lamarque et al., 2011; Seppelt et al., 2012). In our work, looking at the impact of energy crop production, we have assessed the demand for ES by the lay public and farmers by using both quantitative and qualitative social science approaches.

Stated preference analyses reveal not only the amount that people may be prepared to pay, but also the conditions or developments in the environment, which they desire, or want to avoid. In recent years, a growing number of contingency studies were undertaken worldwide, e.g. Degenhardt et al. (1998); Elsasser et al. (2009); Meyerhoff et al. (2010); Tacconi (2012).

Stated preference analyses are applied to determine the appreciation of visitors for particular qualities of nature and the landscape. Such assessments are considered useful to verify the positive effects of nature conservation economically, including in monetary terms (e.g. Gantioler et al., 2010; Woltering, 2012). In a workshop in December 2010 with some two dozen key regional stakeholders from regional planning, biomass production, agriculture - both farmers and representatives of the farmers' association - bioenergy production, conservationist groups, and also representatives of the Saxon State Agency for the Environment, Agriculture and Geology, forestry authorities, the Upper Lusatian Heath and Pond Landscape Biosphere Reserve (the director) and others, some 14 ecosystem services were selected as important for detailed analysis:

\section{Provisioning services}

- Drinking water

- Food production 
- Raw materials for industrial demands such as fibre

- Bioenergy

- Feed for livestock

2. Regulating services

- Habitats for plants and animals

- Pollination

- Flood prevention

- Erosion control

- Carbon storage

3. Socio-cultural services

- Landscape aesthetics

- Outdoor recreation

- Inspiration for hobbies

- Religion/spiritual inspiration.

\subsection{Method for assessing the attitude of farmers toward energy crop production and the provision of ecosystem services}

To address farmers, we opted for a qualitative approach (Atteslander, 2003). A small sample was chosen to develop a more in-depth understanding of human behaviour and the reasons for it. Semi-structured interviews were developed (Marshall and Rossman, 1998). Farmers to be interviewed were selected by using the concept of maximum contrasts (Hunziker, 2000) to encompass the entire range of attitudes and opinions of all types of farms found in the Görlitz district. At the end of an interview, the person was asked if he or she could name someone with an opposing opinion or from a different type of farm, who therefore might have a different view of these issues. Not all of those initially contacted reacted to our approach, and some refused our request for an interview. Almost all farmers were sceptical about being surveyed, but finally twelve persons agreed to be interviewed under this procedure (Tab. 1). One person from the regional planning authority and eleven representatives from different types of farms - large cooperatives and small family-owned farms, and also from organic farms and those planting genetically modified crops - were interviewed. Almost all interviewees rejected having the interviews recorded, although anonymity and privacy were assured.

Since most farmers refused to allow the recording of their interviews, two interviewers were present and noted the statements. These two handwritten records were used to create a single digital file that was analysed using contentanalysis methods (Atteslander, 2003; Mayring, 2000) to obtain answers to the key questions of our semi-structured interviews. The text was edited, shortened and structured to render the key statements comprehensible.

\subsection{Attitudes and perceptions of lay people}

In order to obtain a broad perspective of the population in the Görlitz district, a quantitative approach was chosen (e.g. Degenhardt et al., 1998; Atteslander, 2003). We used short questionnaires with four questions, plus queries on demographic data. Answers were to be checkmarked; only one choice per question was allowed. In the questions involving monetary value (WTP), we wanted to

\begin{tabular}{|c|c|c|}
\hline $\begin{array}{l}\text { Interview } \\
\text { number }\end{array}$ & Interviewee & Description of the farm/institution \\
\hline$\# 1$ & Regional planner & Regional planning authorities, for an external view \\
\hline$\# 2$ & Owner & $\begin{array}{l}\text { Organic family-owned farm in the southern part of the Görlitz district, } 50 \text { ha of agricultural land and } 40 \\
\text { ha of forest; the owner operates his own solar-power plant mounted on a stable, his own wind turbine } \\
\text { and a small biogas plant ( } 70 \mathrm{~kW} \text { electricity generation capacity) using manure }\end{array}$ \\
\hline$\# 3$ & Manager & $\begin{array}{l}\text { Organic farm enterprise in the centre of the district with } 320 \text { ha: } 189 \text { ha of farmland, } 20 \text { ha of forest, } 92 \\
\text { ha of grassland; value adding convenience products sold in whole-food/ health-food shops; } 50 \mathrm{~kW} \text { of heat } \\
\text { energy generation capacity) wood heating }\end{array}$ \\
\hline$\# 4$ & Manager & $\begin{array}{l}\text { Agricultural cooperative of } 1,200 \text { ha in the north of the Görlitz district, } 1000 \text { ha of farmland, } 100 \text { ha of } \\
\text { grassland, } 450 \text { livestock units; co-operative is interested in operating a biogas plant }\end{array}$ \\
\hline \# 5 & Manager & $\begin{array}{l}\text { Limited liability company in the southern part of the district with } 500 \text { ha ( } 25 \% \text { owned, } 75 \% \text { rented), } 230 \\
\text { ha of grassland, } 270 \text { ha of farmland, including } 90 \text { ha of corn; dairy cattle; own biogas plant using manure, } \\
\text { slurry and silage from the grassland }\end{array}$ \\
\hline$\# 6$ & Manager & $\begin{array}{l}\text { Agricultural co-operative in the southern part of the Görlitz district, } 800 \text { ha with major share in } \\
\text { permanent grassland; dairy cattle; own biogas plant using silage from grassland, and slurry }\end{array}$ \\
\hline \# 7 & Manager & $\begin{array}{l}\text { Agricultural co-operative in the northern part of the Görlitz district, operating on } 3,200 \text { ha, } 1,600 \text { ha of } \\
\text { farmland, } 600 \text { ha of grassland; biogas plant began operation in } 2012\end{array}$ \\
\hline$\# 8$ & Manager & $\begin{array}{l}\text { Agricultural co-operative in the centre of the Görlitz district operating on 1,250 ha, 1,000 ha of farmland } \\
\text { and } 250 \text { ha of grasslands; } 500 \text { dairy cattle units; own biogas plant }\end{array}$ \\
\hline \# 9 & Entrepreneur & $\begin{array}{l}\text { Farm enterprise in the centre of the Görlitz district, } 240 \text { ha agricultural land, seed production, no } \\
\text { livestock; operates wood-gasification plant }\end{array}$ \\
\hline \# 10 & Owner & $\begin{array}{l}\text { Family-owned farm in the Upper Lusatian Heath and Pond Landscape Biosphere Reserve breeding } \\
\text { Galloway cattle, } 270 \text { ha }\end{array}$ \\
\hline \# 11 & Owner & $\begin{array}{l}\text { Small family-owned farm in the Upper Lusatian Heath and Pond Landscape Biosphere Reserve, } 18 \text { ha, } \\
12 \text { ha of farmland, } 6 \text { ha of grassland, recently taken over from parents }\end{array}$ \\
\hline \# 12 & Owner & $\begin{array}{l}\text { Family-owned farm in the southern part of the Görlitz district, } 2 / 3 \text { owned, 1/3 rented land, } 325 \text { ha of } \\
\text { farmland, } 30 \text { ha of grassland; } 1,900 \text { feeding pigs }\end{array}$ \\
\hline
\end{tabular}

Tab. 1: Interviewees and a brief description of their farms 
know whether the respondent would be prepared to pay a predefined amount of money. Open-ended questions involved their willingness to pay (amount in Euros), and their opinion as to where to cut budgets to obtain money for conservation measures. Since the region is characterized by demographic change, there is a large proportion of elderly persons, and many long-distance or weekend commuters to the district. To get a good cross-section of interviewees, we decided to carry out "market-square surveys", choosing frequented places - a shopping centre and two festival events - on weekends, so as to reach more inhabitants. With this approach, rather than sending questionnaires, we intended to avoid a bias in favour of respondents more interested in nature, who might respond more frequently than others.

We validated our interviews by using a second interview site in Templin (16,237 inhabitants in 2011, according to the 2013 Census Map) in the district of Uckermark, in the neighbouring state of Brandenburg. The Uckermark district, with 305,841 ha (Destatis, 2013), is a different kind of region physically, located entirely in the North German Plain. The two regions are to some extent comparable from a socioeconomic point of view, in that both are peripheral regions with high unemployment and decreasing population, and are dominated by the agricultural sector.

Our selected interview sites and the number of collected interview sheets can be found in Table 2 . Altogether 249 interview sheets were completed.

Post-modern sociological theories posit a pattern of individualization with a wide range of options for designing one's life. Schulze (1997), however, contends that socialization leads to similarities in behaviour patterns in terms of groups - his so-called "lifestyles" - which can be observed, sharing values, norms, tastes and preferences.
Some studies indicate that value orientations (Müller and Job, 2009; BMU, 2009; UBA, 2009), or "lifestyles", strongly influence perceptions, consciousness and attitudes towards the environment (UBA, 2009). In this study we used Schulze's Lifestyle-Group Concept: five groups with specific behaviour patterns (Tab. 3). The five groups are defined by education level and by age (above and below age 40 , respectively). According to Schulze (1997), persons tend to revise their behaviour patterns between 40 and 45 .

Despite its tendency toward stereotyping, and some fuzziness in assigning individuals to certain lifestyles, Schulze's Lifestyle-Group concept helps provide an understanding of the everyday lives and realities of people. It covers many aspects regarding communication channels, general preferences and the home leisure-time activities of different groups.

Since our questions contain nominal and ordinal scales, we had to use non-parametric tests. We opted for a posthoc analysis of our data to detect possible differences or correlations between different subgroups of our sampled population. We tested the results according to these different groups, as well as between the two different districts, to examine the statements from Görlitz district in comparison to the Uckermark District results, using Chi-square tests in pairwise comparisons and Anova Scheffé tests for the different lifestyle groups.

\section{Results}

\subsection{The farmers' perspectives}

\subsubsection{Self-perception of farmers}

All farmers perceive themselves as modern entrepreneurs, producing according to market conditions, no matter what

\begin{tabular}{|l|l|c|c|c|}
\hline \multicolumn{1}{|c|}{ Interview site } & \multicolumn{1}{|c|}{ Date } & Duration & $\begin{array}{c}\text { Completed } \\
\text { sheets }\end{array}$ & $\begin{array}{c}\text { Estimated } \\
\text { response rate }\end{array}$ \\
\hline Görlitz, downtown shopping centre & $\begin{array}{l}\text { Saturday, March 10, 2012, a day when } \\
\text { an education fair and exhibition was } \\
\text { being held at the centre }\end{array}$ & $10: 00-16: 00$ & 71 & $25 \%$ \\
\hline Nochten Music Festival & Friday, April 27, 2012 & $16: 30-18: 00$ & 26 & $70 \%$ \\
\hline $\begin{array}{l}\text { Löbau, Saxon Horticultural Festival } \\
\text { and Exhibition Area }\end{array}$ & $\begin{array}{l}\text { Thursday May 18, 2012 } \\
\text { (public holiday weekend) }\end{array}$ & $10: 00-16: 00$ & 113 & $80 \%$ \\
\hline Templin, downtown shopping area & $\begin{array}{l}\text { Saturday, April 28, 2012; the day of the } \\
\text { annual spring district fair } \\
\text { (validation for the Görlitz results) }\end{array}$ & $10: 00-16: 00$ & 39 & $30 \%$ \\
\hline
\end{tabular}

Tab. 2: Interview sites, dates, duration of collecting interviews, completed sheets and estimated response rate

\begin{tabular}{|l|c|l|c|}
\hline \multicolumn{1}{|c|}{ Lifestyle-group } & Age & Correlating everyday leisure behaviour patterns & $\begin{array}{c}\text { Level of formal } \\
\text { education }\end{array}$ \\
\hline Unterhaltung ("Entertainment") & $<40$ & $\begin{array}{l}\text { Listening to rock, pop, easy listening music, reading } \\
\text { tabloids, watching quiz shows }\end{array}$ & Low \\
\hline Selbstverwirklichung ("Self-fulfilment") & $<40$ & $\begin{array}{l}\text { Listening to rock, pop, classical music, going to theatre } \\
\text { performances, reading quality newspapers }\end{array}$ & High \\
\hline Harmonie ("Harmony") & $>40$ & $\begin{array}{l}\text { Listening to easy-listening music, reading tabloids, } \\
\text { watching quiz shows }\end{array}$ & Medium \\
\hline Integration ("Integration") & $>40$ & $\begin{array}{l}\text { Listening to classical music, easy listening music, } \\
\text { watching quiz shows, }\end{array}$ & High \\
\hline Niveau ("High-Class") & $>40$ & $\begin{array}{l}\text { Listening to classical music, going to theatre, reading } \\
\text { quality newspapers }\end{array}$ & . \\
\hline
\end{tabular}

Tab. 3: Lifestyle-Group Concept, following Schulze (1997) 
type of farm they operate. They do emphasize, however, the importance of tradition - they want to be perceived as food producers. Most of our interviewees do not really like being called "energy farmers". In their opinion, energy should be just one of their farm products, and should not gain too much importance in their portfolios. The production of bioenergy should be directly connected with operating a farm. Interestingly, although we had some famers experienced in cultivating or using genetically modified plants on our panel, only two interviewees (\# 4 and 12) saw genetic engineering as an appropriate solution to a range of problems, from feeding humankind to energy production; \# 8 and all the other farmers were critical of GMOs.

At the beginning of the interviews, without any questions being posed, or the concept of ES even being mentioned, some farmers already referred to their commitment and responsibility to provide other goods and services for the sake of society, or non-commodity outputs beyond food and energy (\#s 1, 2, 6 and 9). In their self-image, they see themselves as providers of ES, although they do not use this term.

\subsubsection{Land use conflicts}

The biggest problem for all interviewees was the rise in prices and rents for farmland, due to speculation and land grabbing by non-agricultural investors, which is seen as a general trend unrelated to the bio-energy boom (\#s 3, 5, 7, 8 and 10). In particular, the owners of small farms feel disadvantaged when trying to rent fields. Besides demand for biomass production, farmers complain of significant land loss without compensation due to opencast lignite mining (interviewees in the north of Görlitz district \#s 4, 7 and 8), reforestation programs and excessive construction of infrastructure and housing, although the Görlitz district lost $25 \%$ of its inhabitants between 1990 and 2011 (Statistisches Landesamt, 2012). For the organic farms (\#s 2 and 3), and also the seed-producing company (\# 9), the increasing cultivation of GMOs is perceived as an existential threat. One of the interviewees (\# 3) described the immense efforts needed to protect the farm from contamination by these organisms. Some of the interviewees stated that the increased conflict between biomass cultivation and food production is just a media issue, not a real one, and that the impacts upon the landscape are largely aesthetic (\#s 4, 5 and 7).

The two organic farm interviewees (\#s 2 and 3) did identify increased bio-energy production as a major threat to the success of their business model, e.g. due to contamination by GMO pollen. These two persons also mentioned the negative impact on soil carbon storage and pollination. All interviewed farmers saw the limits of energy crop cultivation.

Rising groundwater levels caused by abandoning lignite mining and converting the former open-cast mines into lakes is a major issue for many interviewees, especially for those in the northern part of the district (\#s 3, 4, 7, 8, 10 and 11). All of them want an institution responsible for maintaining the ditches in order to restore a functioning landscape water regime. Two conventional farmers (\#s 4 and 7) see a necessity for further drainage, while the manager of the organic farm (\# 3) thought that short-rotation coppice could be a possible alternative for his sites affected by stagnant moisture.

\subsubsection{Climate change and adaptation}

With the exception of three interviewees (\#s 8, 10 and 11, all located in the south, on better soils), all farmers see themselves confronted with the need to adapt to a changing climate. Climate change is perceived primarily in terms of extreme weather events: examples included extremely rainy phases in early spring, followed by an early summer drought, and then extreme summer rain, causing soil erosion, flooding, often combined with damage due to hail, etc. The interviewees had different coping/adaptation strategies. Wells for sprinkle irrigation (\#s 2 and 4), experiments with more drought resistant crops (\#s 2, 3, 5 and 7), or alternative cultivation systems, such as plough-free farming. One of the organic farmers (\# 2) even mentioned experiments with viniculture, due to the warmer climatic conditions in recent years. Two of the conventional farm managers stated that GMO plants would not solve the problems arising from climate change (\#s 5 and 7).

\subsubsection{Importance of regional planning and subsidies}

Regional planning is not considered relevant for farmers. Its position would improve if it was used to identify and allocate regions for certain types of subsidies (\# 1). With respect to subsidies and dependency on EU payments, as well as to the importance of payments from the operation of biogas plants, the farmers gave evasive answers. It can be assumed that direct CAP payments (around $€ 300 /$ ha/year in Germany by 2012) and the revenues gained by providing electricity to the grid under the Renewable Energy Act, are important pillars of their income structure. Interestingly, a number of interviewees (\#s 2, 4, 5, 6, 8 and 9) from all different types of farms stated that they would prefer free markets, if the general framework for agriculture were established differently, e.g. if prices for food were fair and such external effects as direct or indirect subsidies like those to the transportation sector, were ended. Also, recent EU Cross-Compliance regulations involving considerable paperwork and controls, which the interviewees saw as timeconsuming and extremely complex, may have affected these responses. It can be assumed that environmental programs are also an important source of income, but four farmers mentioned a lack of consistency and the long-term character of these programmes (especially \#s 2, 4 and 8). The regional planner (\# 1) stated that regional planning should be better combined with environmental programs, so as to provide better effects for biodiversity and Ecosystem Services.

\subsubsection{Bio-energy and farming}

Bio-energy is important for all interviewees. Many of the farmers have already their own wood heating (\#s 2, 3 and 9) or biogas plant (\#s 5, 6, 7 and 8), or are considering to install one (\# 4). Corn is the most important feed, but manure, slurry and silage grasses are used as well. One of the farms (\# 7) was experimenting with switch grass (Panicum virgatum) at the time of the interviews. Most of the interviewed farmers used the cultivated energy crops themselves and only two (\#s 2 and 4) sold it to other entrepreneurs. The farmers were unable to tell whether their wheat or rapeseed was used for energy purposes or not. Vendors or middlemen decide whether the products are sold for food or fuel production, and the farmers can virtually never ascertain what happens to their crops.

All of the interviewees felt that bio-energy production should always be associated with a farm, and that the size of a biogas plant should correlate with the amounts of raw material that could be delivered from the surrounding area. Also, transport distances should be limited to $10 \mathrm{~km}$ around the biogas plant, and transport costs should also include the costs paid by society in general (e.g. wear and tear on roads due to heavy trucks). 


\subsubsection{Perennial crops, wood biomass and landscape management residues}

All except four of the interviewed famers rejected perennial crops and short-rotation coppice. On the one hand, it was perceived as being incompatible with farming. On the other, these cultures cause severe problems when plants are replaced in favour of others, since root penetration is intense. Also, compared with other crops, short-rotation coppice and dedicated energy crops have few marketing options. Only two interviewees had generally positive attitudes: one (\# 4) stated that the examples in the regions for shortrotation coppice are not convincing, while another (\# 10) could imagine cultivating willow and poplar plantations as a second independent enterprise. Also, farmer \# 7 felt positively about growing Miscanthus, and farmer \# 9 was in favour of such crops on the former lignite opencast mines. The organic farmer (\# 2) stated that only residues and material from landscape management are suitable sources for bio-energy. Many other interviewees shared this view, but aside from the organic farmers (\#s 2 and 3), only one other farm owner systematically planted hedgerows (\# 4). Most of the interviewees stated that it would be difficult to manage these structures with the existing machinery.

\subsection{Lay people's perspectives}

Looking at our sample data, younger persons less than 18 years of age are underrepresented, while persons in the age groups between 41 and 65 are overrepresented, when comparing them to the official census data (Zensus, 2011). Persons with a higher formal education background and their lifestyles are overrepresented in our sample. As in other surveys, persons with lower formal education levels tend not to participate or refuse more frequently (some discussion about this can be found e.g. in Schulze, 1997 and BfN, 2011).

On a preference scale from 1 (not important) to 5 (very important), the provision of drinking water, food production and biodiversity (referred to as "wild animals and plants" in our questionnaire) were considered the most important ecosystem goods and services (Fig. 3). In the perceptions of people from the Görlitz district, flood prevention was considered significantly more important than it was in the Uckermark, where floods were not perceived as a major risk. This can be explained by two severe floods along the Lusatian Neisse (the district's eastern border with Poland) in 2010 and 2011.

Significant differences between lifestyle groups were found mainly among younger persons with higher formal education ("Self Fulfilment"). They tend to attach less importance to such services as outdoor recreation opportunities, inspiration for hobbies, flood prevention, feed for livestock, landscape aesthetics and erosion control. While landscape aesthetics, outdoor recreation, erosion control and flood prevention tend to become more important for lifestyles characterized by older age people, inspiration seems to be less important for those characterized by higher education.

Most respondents, by far, want to limit biomass production to areas not needed for food production, with the focus on residues and landscape management materials (Fig. 4, only one selection possible). There were no significant differences between Templin and Görlitz district interviewees in this respect, or between different lifestyle groups. A large majority (85\% of the interviewees) demanded better conditions for biodiversity and ES provision on agricultural land. Here, too, there are no significant differences between interviewees in the two districts or between the lifestyle groups.

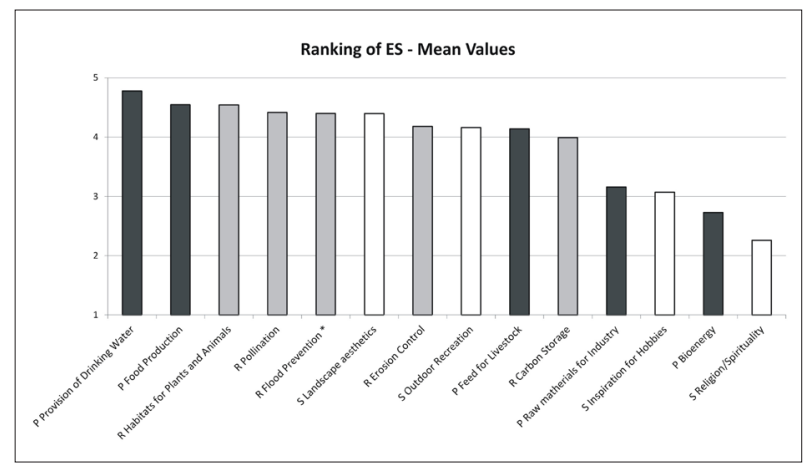

Fig. 3: Values of ecosystem services by surveyed lay people on a scale from 1 (not important) to 5 (highly important). Colours and abbreviations: Black; $R=$ Provisioning Services, Grey; $R=$ Regulating Services, White; $S=$ Socio-cultural Services, * significant difference between the Görlitz and Uckermark District interviewees

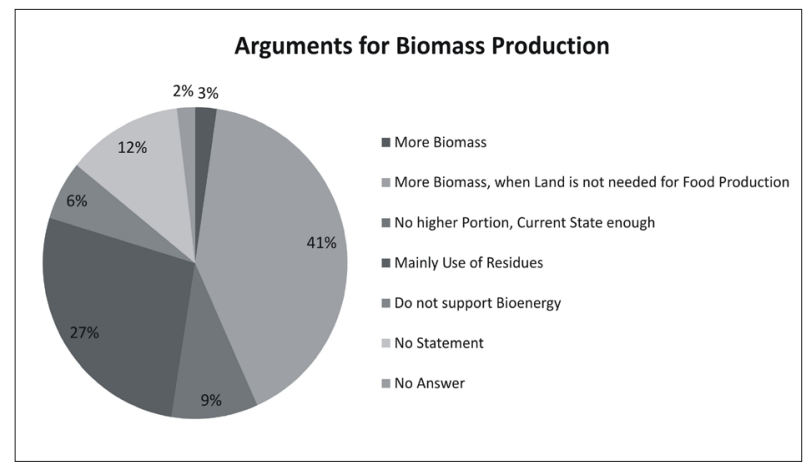

Fig. 4: Responses of surveyed lay people to the question of whether biomass production should continue to be supported/support be increased

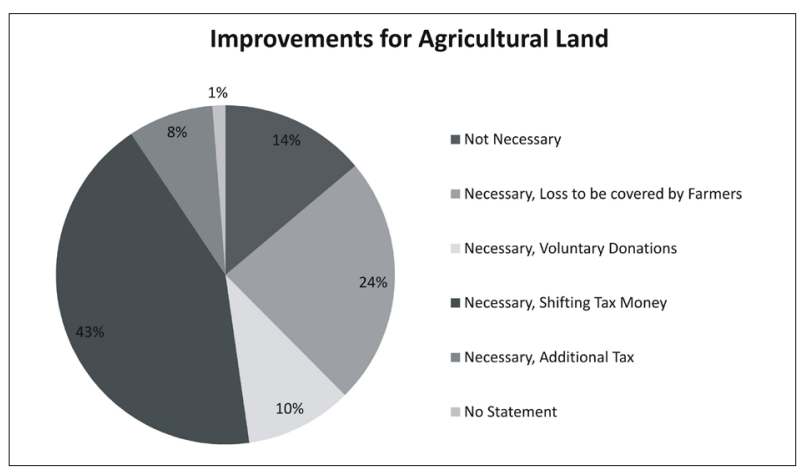

Fig. 5: Responses of surveyed lay people to the question of spending money for the improvement of ecosystem services on agricultural land

While roughly one quarter of interviewees stated that possible extra costs and potential losses should be covered by farmers, a majority of interviewees wanted to spend more money to support ES by shifting more tax money (mainly defence, if interviewees named a budget item where money might be cut). However, a number of participants were also willing to pay more in taxes or voluntary donations. The amount which those willing suggested as payment averaged $€ 13.25$, which would be roughly $€ 0.85$ per capita per year and would sum up to nearly €225,000 in the Görlitz district.

\section{Discussion}

It is difficult to assess the extent and location of areas needed for energy crop cultivation. With the aid of GIS, 
we have a tool to describe at least partially the spatial impact of corn production for biogas plants. Compared to German regions like Ammerland with a 70\% share of corn (Deutsches Maiskommitee, 2013) on arable land, relatively small amounts of corn are grown in the Görlitz district, and an even smaller amount is used for energy production. If the ambitious political targets set for energy derived from biomass production and regulation are not changed, this increase would be based mainly on a few annual energy crops, especially corn (FNR, 2012). Due to its negative effects, there is a need for better regulation of the cultivation of energy crops, for the support of farmers who opt for less harmful crops, and for the promotion of alternatives, and a diversified crop rotation.

Key stakeholders see biomass production as still of minor importance in the Görlitz District, as compared to the other parts of Germany, especially in the states of Lower Saxony and Schleswig-Holstein. Therefore, biomass cultivation in the study area could still be somewhat increased from this perspective (Fleischer and Syrbe, 2013). But it should be realized with wood biomass and non-edible energy plants. Strictly speaking, transport and other energy inputs such as fertilizers should be restricted, and humus loss must be avoided in order to keep the carbon balance of bio-energy within the positive range (Leopoldina, 2012). Farmers interviewed in this project also strongly supported such a future course. Almost all of them demanded stricter regulation, as well as laws and incentives to promote better spatial regulation of biomass cultivation and to avoid intensive cultivation of energy crops in sensitive areas, such as protected areas or slopes prone to erosion. There is a strong feeling that binding rules to secure sustainability and some minimum standards are necessary, and should apply to everyone participating in the bio-energy sector. The options for that exist in the Renewable Energy Act according to article $64 \mathrm{~b}$, but are not used yet.

Lay people have a critical attitude toward an unrestricted increase of biomass production, which is primarily forced by subsidies or quota regulations for a target share of renewable sources of energy. From lay perspectives, most people prefer that biomass production focus on areas not necessary for food production, with a stronger focus on residues, landscape management materials or waste. The relatively slight importance that lay people attach to bio-energy production is in line with other studies. In the Europe-wide study Eurobarometer (2010), for example, 56\% of interviewed persons identified the production of healthy food and 25\% environmental protection, as core goals for farming activities; only $8 \%$ named biomass production for energy purposes. The fact that the result in the Görlitz and Uckermark districts are similar is especially notable, since our surveys were carried out after the Fukushima nuclear accident, which sparked a shift in German energy policy towards renewable energy sources, so that these sources thus received much media attention.

The surprisingly high appreciation for such assets as "habitats for plants and animals", "pollination" or "landscape aesthetics" is comparable with the results of other recent studies in Germany (cf. BfN, 2011; Grunewald et al., 2012). It can be stated that there is a high acceptance and even an expressed demand for biodiversity and nature protection among all groups in society. Many other surveys on nature consciousness also indicate a huge demand of high environmental standards and a great relevance for environmental protection throughout society, especially by persons characterized as trendsetters and role models
(Lupp and Konold, 2008; BfN, 2009; Sinus Sociovision, 2009; UBA, 2009). The BfN study (BfN, 2009) also indicates a demand among many groups in society for stricter laws to better protect ES, and to provide offset payments for the destruction of nature. It is questionable, however, whether the expressed willingness to pay would gain such high acceptance if a new tax were to be implemented, or donations were to be made to permit agricultural land to be used for recreational purposes.

\section{Conclusions}

Although the majority of surveyed laypersons may not be familiar with energy derived from energy crops and their impacts on ES and the environment, they feel the ambiguity of this energy source with respect to its side effects. Bioenergy will only gain acceptance if the focus is placed on the use of residues and other non-food crops in the future. Dedicated energy crops, which can benefit ES, may therefore be the basis for a strategy which could gain acceptance, especially for intensively-used agricultural landscapes. They could improve the ecological situation and landscape scenery, and win greater acceptance than corn or rapeseed. Not only lay people, but also farmers set great value in providing and enhancing ES. Improved legal frameworks and incentives are appreciated as safeguards for equal competition while maintaining and enhancing ES. The use and cultivation of alternative crops has to be started however. Strong regional networks between operators of biomass plants and farmers can be one key strategy to overcome the problem of the very limited marketability for perennial crops or residues.

\section{Acknowledgements}

We would like to thank the German Federal Ministry of Research and Education for funding this research work under the funding priority "Sustainable Land Use - Module B" FKZ 033L028A-E, and Birgit Fleischer, Dana Kluge, Kristin Lüttich and Harald Neitzel for their assistance in the interviews with farmers and lay people. Finally, we would like to thank Phil Hill, Berlin, for polishing the language.

\section{References:}

Agentur für Erneuerbare Energien (2013): Potenzialatlas Bioenergie in den Bundesländern. [cit. 17.6.2013] Available at: http://www.unendlich-viel-energie.de/de/ service/mediathek/ bioenergie-bundeslaenderatlas.html

ATTESLANDER, P. (2003): Methoden der empirischen Sozialforschung. De Gruyter, Berlin, New York, 411 pp.

BASTIAN, O, LUPP, G., SYRBE, R.-U.; STEINHÄUßER, R. (2013): Energy Crops - Spatial differentiation of Risks. Ekologia, Vol. 32, No. 1, p. 13-29.

BfN - Federal Agency for Nature Protection,(2009): Naturbewusstsein 2009 - Bevölkerungsumfrage zu Natur und biologischer Vielfalt. Bonn, 66 pp.

BfN - Federal Agency for Nature Protection, 2011. Naturbewusstsein 2011 - Bevölkerungsumfrage zu Natur und biologischer Vielfalt. Bonn, 81 pp.

BMBF - Federal Ministry of Education and Research (2008): Announcement of regulations for the "Sustainable land management" funding measure, Bonn.

BMU (Federal Ministry for the Environment, Nature Conservation and Nuclear Safety) (2011): Erneuerbare Energie in Zahlen - Internetupdate ausgewählter Daten. 
Bonn, Berlin. [cit. 3.7.2012 ] http://www.erneuerbareenergien.de/files/pdfs/allgemein/application/pdf/ee zahlen_internet-update.pdf.

BMU (Federal Ministry for the Environment, Nature Conservation and Nuclear Safety) (2010): Energiekonzept für eine umweltschonende, zuverlässige und bezahlbare Energieversorgung. Bonn, Berlin. [cit. 3.7.2012] Available at: www.bmu.de/files/pdfs/allgemein/application/pdf/ energiekonzept_bundesregierung.pdf.

BMELV and BMU (2009): Nationaler Biomasseaktionsplan für Deutschland. Beitrag der Biomasse für eine nachhaltige Energieversorgung. Berlin, $32 \mathrm{pp}$.

BROWN, J., ISAAK, D. (2005): The World Cafe: Shaping Our Futures Through Conversations That Matter. BK Publishers, San Francisco, 242 pp.

Bundesregierung Deutschland (2010): Energiekonzept für eine umweltschonende, zuverlässige und bezahlbare Energieversorgung. Berlin, Deutschland: Bundesministerium für Wirtschaft und Technologie (BMWi) und Bundesministerium für Umwelt, Naturschutz und Reaktorsicherheit (BMU) (Federal Ministry for Economy and Technology, and Federal Ministry for Environment, Conservation, and Reactor Safety), $40 \mathrm{pp}$.

BURGER, F. (2006): Zur Ökologie von Energiewäldern. In: Die Auswirkungen erneuerbarer Energien auf Natur und Landschaft. Schriftenreihe des Deutschen Rates für Landespflege 79, p. 74-80.

CHERUBINI, F., STRØMMAN, A. H. (2011): Life cycle assessment of bioenergy systems: State of the art and future challenges. Bioresource Technology, No. 102: p. $437-451$.

Commission of the European Union (2007): Renewable Energy Road Map - Renewable energies in the $21^{\text {st }}$ century: Building a more sustainable future. Communication from the Commission to the Council and the European Parliament: Brussels.

DEGENHARDT, S., HAMPICKE, U., HOLM-MÜLLER, K., JAEDICKE, W., PFEIFFER, C. (1998): Zahlungsbereitschaft für Naturschutzprogramme. Angewandte Landschaftsökologie 25, Federal Agency for Nature Conservation, Bonn, xx pp.

Deutscher Bauernverband (2012): Der Mais - Anbau und Verwendung. [cit. 3.7.2012] Available at: http://www. bauernverband.de/mais

Destatis: GENESIS Online Datenbank: [cit. 25.9.2013] Available at: https://www.genesis.destatis.de

Deutsches Maiskomitee (2012): Maisanbau/Viehbesatz. Fakten, Statistik, Deutschland, [cit. 3.7.2012] Available at: http://www.maiskomitee.de/web/public/Fakten.aspx/ Statistik/Deutschland/Maisanbau Viehbesatz

EC 2009: Directive 2009/28/EC of 23 April 2009 on the promotion of the use of energy from renewable sources and amending and subsequently repealing Directives 2001/77/EC and 2003/30/EC.

ELSASSER, P., MEYERHOFF, J., MONTAGNÉ, C. \& STENGER, A. (2009). A bibliography and database on forest valuation studies from Austria, France, Germany and Switzerland - A possible base for a concerted European approach. J Forest Econ 15: p. 93-107.
Eurobarometer No. 336 (2010): Europäer, Landwirtschaft und gemeinsame Agrarpolitik (esp. p. 70) Available online at: http://ec.europa.eu/public_opinion/archives/ ebs/ebs_336_de.pdf.

FLEISCHER, B., SYRBE, R.-U. [eds.]: Nachhaltige Nutzung von Energiepflanzen für eine regionale Entwicklung im Landkreis Görlitz. Ein Handlungsleitfaden. Internationales Begegnungszentrum St. Marienthal (IBZ) und LeibnizInstitut für ökologische Raumentwicklung Dresden (IÖR), 81 pp. [cit.25.9.2013] Available at: http://www.loebestein. de/documente/Handlungsleitfaden_web.pdf.

FNR (Fachagentur nachwachsende Rohstoffe) (2012): Anbaufläche für nachwachsende Rohstoffe 2012 [cit. 3.7.2012] Available at: http://mediathek.fnr.de/grafiken/ daten-und-fakten/anbauflache-fur-nachwachsenderohstoffe-2012.html.

HALL， R. L., ALLEN, S. J., ROSIER, P.T.W., SMITH, D. M., HODNETT, M. G., ROBERTS, J. M.; HOPKINS, R., DAVIES, H. N. (1996): Hydrological effects of short rotation energy coppice. Institute of Hydrology, Wallingford, UK, $201 \mathrm{pp}$.

HEIDMANN, T., THOMSEN, A., Schelde, K. (2000): Modelling soil water dynamics in winter wheat using different estimates of canopy development. Ecological Modelling, No. 129, p. 229-243.

HUNZIKER, M. (2000): Einstellung der Bevölkerung zu möglichen Landschaftsentwicklungen in den Alpen. Eidgenössische Forschungsanstalt WSL, Birmensdorf (CH), $157 \mathrm{pp}$.

KAVALOV, B., PETEVES, S. D. (2005): Status and perspectives of biomass-to-liquid fuels in the European Union. Mission of the Institute for Energy Office for Official Publications of the European Communities, Luxembourg. $126 \mathrm{pp}$.

LAMARQUE, P., TAPPEINER, U., TURNER, C., STEINBACHER, M., BARDGETT, R. D., SZUKICS, U., SCHERMER, M., LAVOREL, S. (2011): Stakeholder perceptions of grassland ecosystem services in relation to knowledge on soil fertility and biodiversity. Regional Environm. Change, No. 11,p. 791-804.

Leopoldina (2011): Stellungnahme Bioenergie: Möglichkeiten und Grenzen. Leopoldina National Academy of Sciences. Halle, $132 \mathrm{pp}$.

LEE, Y. H., BÜCKMANN, W., HABER, W. (2008): BioKraftstoff, Nachhaltigkeit, Natur- und Bodenschutz. NuR (Natur und Recht), No. 29, p. 821-831.

LIESEBACH, M., MULSOW, H. (2003): Der Sommervogelbestand einer Kurzumtriebsplantage, der umgebenden Feldflur und des angrenzenden Fichtenwaldes im Vergleich. Die Holzzucht, No. 54, p. 27-31.

LONDO, M., ROOSE, M., DEKKER, J., DeGRAAF, H. (2004): Willow short-rotation coppice in multiple land-use systems: evaluation of four combination options in the Dutch context. Biomass and Bioenergy, No. 27,p. 205-221.

LUPP, G., KONOLD, W. (2008): Landscape Preferences and Perception of Both Residents and Tourists: A Case Study in Müritz National Park (Germany). In: Siegrist, D.; Clivaz, C.; Hunziker, M.; Iten, S. [eds.]: Visitor Management in Nature-based Tourism -Strategies and Success Factors for Parks and Recreational Areas, 
Series of the Institute for Landscape and Open Space, HSR University of Applied Sciences Rapperswil 2, Rapperswil, p. 47-58.

LUPP, R., STEINHÄUßER, R., STARICK, A., GIEß, M., BASTIAN, O., ALBRECHT, J. (2014): Forcing Germany's renewable energy targets by increased energy crop production - A challenge for regulation to secure sustainable land use practices. Land Use Policy, No. 36, p. 296-306.

MARSHALL, C., ROSSMAN, G. B. (1998). Designing Qualitative Research. Thousand Oaks, CA: Sage. 321 pp.

MAYRING, P. (2000): Qualitative Inhaltsanalyze Grundlagen und Techniken, 7. Auflage. Beltz Deutscher Studien Verlag, Weinheim, Basel, 135 pp.

McLAUGHLIN, S. B., WALSH, M. E. (1998): Evaluating environmental consequences of producing herbaceous crops for bioenergy. Biomass and Bioenergy, No. 14, p. $317-324$.

MEYERHOFF, J., ANGELI, D., HARTJE, V. (2010): Social benefits of implementing a national strategy on biological diversity in Germany. $12^{\text {th }}$ Int. BIOECON Conf. "From the Wealth of Nations to the Wealth of Nature: Rethinking Economic Growth," Venice, Sep. 27-28, 2012. Retrieved from - http//www.bioecon. ucl.ac.uk/12th_2010/Angeli.pdf [cit. 25.9. 2013].

MITTELSTRASS, J. (2002): Transdisciplinarity - New Structures in Science. In: Max-Planck-Gesellschaft [ed.]: Innovative Structures in Basic (Ringberg Symposium October 4-7, 2000). Munich, p. 43-57.

MÜLLER, F., BURKHARD, B. (2007): An ecosystem based framework to link landscape structures, functions and services. In: Mander, U., Wiggering, H., Helming, K. [eds.]: Multifunctional land use - Meeting future demands for landscape goods and services. Springer, Berlin, Heidelberg, New York, p. 37-64.

MÜLLER, M., JOB, H. (2009): Managing natural disturbance in protected areas: Tourists' attitude towards the bark beetle in a German national park. Biological Conservation, No. 142, p. 375-383.

NORGAARD, R. B. (2010): Ecosystem services: From eyeopening metaphor to complexity blinder. Ecol. Econ., Vol. 69, No. 6: p. 1219-1227.

RODE, M., KANNING, H. (2006): Beiträge der räumlichen Planung zur Förderung eines naturund raumverträglichen Ausbaus des energetischen Biomassepfades. Informationen zur Raumentwicklung, H. 1. Bonn, p. 103-110.

ROWE, R. L., STREET, N. R., TAYLOR, G. (2009): Identifying potential environmental impacts of large-scale deployment of dedicated bioenergy crops in the EU. Renewable and Sustainable Energy Reviews, No. 13: p. 271-290.
SCHRAMEK, J., OSTERBURG, B., KASPERCZYK, N., NITSCH, H., WOLFF, A., WEIS, M., HÜLEMEYER, K. (2012): Vorschläge zur Ausgestaltung von Instrumenten für einen effektiven Schutz von Dauergrünland. BfN Skript 323, Bonn-Bad-Godesberg. 112 pp.

SCHULZE, G. (1997): Die Erlebnisgesellschaft: Kultursoziologie der Gegenwart, 7th ed. Campus, Frankfurt, New York, 765 pp.

SCHWEPPE-KRAFT, B. (2009): Natural Capital in Germany - State and Valuation; with special reference to Biodiversity. In: Döring, R. [ed.]: Sustainability, natural capital and nature conservation. Marburg, $24 \mathrm{pp}$.

Sinus Sociovision (2009): Kommunikation zur AgroBiodiversität - Voraussetzungen für und Anforderungen an eine integrierte Kommunikationsstrategie zu biologischer Vielfalt und genetischen Ressourcen in der Land-, Forst-, Fischerei- und Ernährungswirtschaft (einschließlich Gartenbau). Study for the Federal Ministry of Food, Agriculture and Consumer Affairs, $189 \mathrm{pp}$.

Statistisches Landesamt (2012): Bevölkerung des Freistaates Sachsen am 31 Dezember 1990, 1995, 2000, 2005 und 2008 bis 2011 nach Kreisfreien Städten und Landkreisen. [cit. 27.11.2012] Available at: http://www.statistik.sachsen. de/download/010_GB-Bev/02_02_01_tab.pdf

SEPPELT, R., FATH, B., BURKHARD, B., FISHER, J. L., GRĘT-REGAMEY, A., LAUTENBACH, S., PERTH, P., HOTES, S., SPANGENBERG, J. H., VERBURG, P. H., VAN OUDENHOVEN, A. P. E. (2012): Form follows function? Proposing a blueprint for ecosystem service assessments based on reviews and case studies. Ecol. Indic., No. 21, p. 145-154.

SRU (Sachverständigenrat für Umweltfragen) (2007): Klimaschutz durch Biomasse. Special Report, Bonn, 48 pp.

TACCONI, L. (2012): Redefining payments for environmental services. Ecol. Econ., No. 73, p. 29-36.

UBA [ed.] (2009): Umweltbewusstsein und Umweltverhalten der sozialen Milieus in Deutschland. Dessau-Roßlau, $132 \mathrm{pp}$.

WEITH, T., SCHULZ, K., GAASCH, N., SEPPELT, R., WERNTZE, A., EPPINK, F. V. (2010): Towards integration: Sustainable land management: A new German research funding measure. Local Land \& Soil News (34/35), p. 21-22.

WOLTERING, M. (2012): Ökonomische Effekte von Großschutzgebieten. Naturschutz und Landschaftsplanung, Vol. 44, No. 11, p. 325-331.

Zensus (2011): Zensus. Internet source. [cit. 25.9.2013] Available at: https://ergebnisse.zensus2011.de/?locale=en\#

Zensuskarte 2013. Census Map. [cit. 25.9.2013] Available at: www.zensuskarte.de

\section{Authors'addresses:}

Gerd LUPP

Strategic Landscape Planning and Management

Emil-Ramann-Str. 6, 85354 Freising, Germany

e-mail: gerd.lupp@tum.de 
Olaf BASTIAN, e-mail: o.bastian@ioer.de

Ralf-Uwe SYRBE, e-mail: r.syrbe@ioer.de

Leibniz Insitute of Ecological Urban and Regional Development

Weberplatz 1, 01217 Dresden, Germany

\section{Reimund STEINHÄUßER}

Leibniz Centre for Agricultural Landscape Research

Eberswalder Straße 84, 15374 Müncheberg, Germany

e-mail: reimund.steinhaeusser@zalf.de

Initial submission 30 October 2013, final acceptance 30 April 2014

Please cite this article as:

LUPP, G., BASTIAN, O., STEINHÄUßER, R., SYRBE, R.-U. (2014): Perceptions of energy crop production by lay people and farmers, using the ecosystem services approach. Moravian Geographical Reports, Vol, 22, No. 2, p. 15-25. DOI: 10.2478/mgr-2014-0008. 